\title{
Przechadzki
}

\section{Okna Jana Potockiego}

Krzysztof Mrowcewicz

TEKSTY DRUGIE 2020, NR 6, S. 353-367

DOI: 10.18318/td.2020.6.21 | ORCID: 0000-0002-8533-4178

...pomnażał się nieskończenie w przeciwległych lustrach; nużył się otwieraniem i uchylaniem okien, które odsłaniały przed nim na zewnątrz ten sam zaniedbany ogród [...] Dom nie jest tak duży - pomyślał - Powiększają go półmrok, symetria, lustra, liczne lata, moja samotność...

J.L. Borges, Śmierć i busola

Oddałby ostatni grosz [...], żeby napisać jedną książczynę i zyskać sławę [...] Zapada więc na suchoty i strzela sobie w łeb, twarzą do ściany.

V. Woolf, Orlando

$\mathbf{N}$ ie zaglądajcie w okna hrabiego Potockiego! Nie zaglądajcie w okna! Niech was nie kusi nieprzyzwoicie uchylona firanka, niedomknięta żaluzja, rozcięta stora, gra cieni na zasłonie. Nie próbujcie się domyślać, co jest w środku.

O, niebezpieczna ciekawości, która każesz nam przekraczać granice! O, rozkoszne wścibstwo, z upodobaniem kąpiące się w strużce okiennego światła! O, obrzydliwa żądzo poznania! Tak, wiedzieć, wiedzieć za wszelką cenę.

\section{Krzysztof}

Mrowcewicz - dr

hab., historyk litera-

tury i kultury, profesor w IBL PAN i Akademii

Teatralnej im. A. Ze-

Iwerowicza; kierownik Zespołu Europeistyki

Literackiej IBL PAN, redaktor naczelny Słownika polszczyzny

XVI wieku; autor kilku książek i wielu rozpraw, popularyzator kultury dawnej; wydawca poezji staropolskiej (w tym, wspólnie z Luigim Marinellim, edycji staropolskiego przekładu L'Adone Giambattisty Marina). Laureat $\mathrm{Na}$ grody "Literatury na Świecie" oraz Nagrody Literackiej Gdynia. 
Wiedzieć i nie być wiedzianym. O, podniecająca perwersjo voyeuryzmu! Widzieć i nie być widzianym. Słyszeć i nie być słyszanym.

Nie zbliżajcie się do okien, nie opuszczajcie bezpiecznego gniazda, ciepłej nory, nie opuszczajcie siebie! Ale oczy nie chcą się zamykać - a przecież są oknami duszy i bramami. I kto jest tak dzielny, tak wstrzemięźliwy i powściagliwy, tak w cnotach wyćwiczony, by odwrócić głowę, gdy okno wodzi na pokuszenie? Ach, zaspokoić żądzę, ach, uśmierzyć swędzące pokuśnie pożądanie!

Świat oglądany z okna, oglądany przez okno jest jak scena, od której odgradza nas niewidzialna szyba, rampa okiennej ramy, balustrada balkonu czy tarasu. U c z e s t n i c zy m y w czymś i zarazem jesteśmy na zewnątrz akcji. Jesteśmy widzami, krytykami, badaczami, korzystamy z naszej wiedzy. Jak rozkosznie, bezpiecznie i miło! Ale wystarczy krok, by konsekwencje były bolesne. Okna są niebezpieczne. O, tak!

Spokojne i uporządkowane życie don Felipe del Tintero Largo, ojca naczelnika Cyganów, toczyło się między dwoma oknami, teatrem i wielkim kałamarzem. Co rano „otwierał drzwi od swego balkonu, który wychodził na ulicę Toledo. Przez kwadrans oddychał świeżym powietrzem, następnie szedł otworzyć drugie okno, które wychodziło na małą uliczkę. Jeśli spostrzegał kogo w oknie naprzeciwko, pozdrawiał go grzecznie, mówiąc «agur»"'. Potem były jeszcze msza u teatynów, domowe porządki, zwijanie dwudziestu czterech cygar. Sześć z nich wypalał, licząc dachówki pałacu księcia Alby, „sześć zaś rachując ludzi przechodzących przez bramę Toledo"2. Po obiedzie wypalał dwanaście pozostałych cygar i szedł do teatru. Rozkosze tytoniu, matematyki i oglądania, wyglądania, spoglądania wypełniały mu całe życie. Do tych niewinnych przyjemności dołączyła jeszcze pasja produkcji atramentu, który zamawiali u niego literaci. Namiętność podobna do pozostałych, bo polegająca na ni e u c z e stnicz eniu. Don Felipe sam nie pisał, ale gdy ukazywało się jakieś głośne dzieło napisane jego atramentem, „z radością uśmiechał się na myśl, że on także należy do tych triumfów"3.

Ale był jeszcze uprzykrzony i nachalny Busqueros, ów kapłan ciekawości, czciciel okiennych tajemnic, mistrz podglądania przez firanki, nieszczelne sufity, dziury wywiercone w deskach, przebiegający z drabiną ulice uśpionego

1 J. Potocki Rękopis znaleziony w Saragossie, przeł. E. Chojecki, oprac. L. Kukulski, Czytelnik, Warszawa 1965, s. 139.

2 Tamże.

3 Tamże, s. 143 . 
miasta. Poznawszy zwyczaje dziwaka, zafundował mu spektakl, który z widowni strącił go na scenę. W opuszczonym mieszkaniu, naprzeciwko okien domu don Felipe, zainstalował swoją krewną, panią Cimento oraz jej synowicę. Obie damy codziennie odgrywały przed samotnikiem osobliwą komedię cnoty i pracowitości. Nie przyjmowały u siebie nikogo i same nigdzie nie wychodziły. Dzień upływał im w milczeniu, na domowych pracach i porządkach. W kącie pokoju, dobrze widocznym z okien naprzeciw, stała szklana szafa napełniona jakimiś słoikami i flaszkami. Przy niej krzątała się pannna Cimento, odziana tylko w lekką spódniczkę i gorsecik, wykonująca jakieś tajemnicze czynności, które przyciągały oczy don Felipe i rozniecały jego ciekawość. Dzięki zręcznemu fortelowi kokietek producent atramentu wkrótce dowiedział się, że jego sąsiadka jest... producentką laku do stemplowania pism i listów, a także kolorowego atramentu!

W spokojne życie don Felipe stopniowo wkradał się chaos. Przestał nawet bywać w teatrze - wystarczył mu ten, który miał w domu naprzeciwko. „Nie mógł oderwać się od okna wychodzącego na małą uliczkę i przypatrywał się, jak panna Cimento ustawia flaszki lub laski laku. Widok dwóch śnieżnych ramion ciągle migających mu przed oczyma, zapalił jego wyobraźnię tak, że

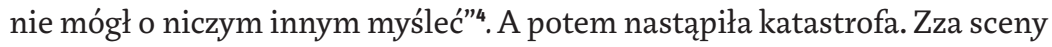
wyszedł Busqueros i rozbiwszy wielki kałamarz don Felipe, doprowadził do czarnego potopu w jego mieszkaniu, który skończył się jeszcze czarniejszą rozpaczą. Naiwny wdowiec dał się bowiem uwikłać w niechciane małżeństwo z panną Cimento, stracił majątek, spokój, wreszcie życie. Panna Cimento rychło zrzuciła bowiem kostium „cichej i potulnej dziewczyny”, pozbyła się śmierdzących palenisk, słojów i kotłów, i przybrała suknie światowej damy, a hiszpańska komedia cnoty i honoru zmieniła się w przepych włoskiej opery. Albo historia szalonego Paszeka.

„Paszeko! Paszeko! W imię twego Odkupiciela!”. Nie zaglądaj przez dziurkę od klucza, choć tam piękna Inezilla już czeka na przyjście kochanka. A serce jej bije na radość i trwogę, a oddech przyspiesza na rozkosz i ból. Nie zaglądaj, nawet w zmyśleniu! I cóż tam możesz zobaczyć? Pukiel włosów, skrawek białej, lekko piegowatej skóry, przysłoniętej nieprzyzwoicie delikatną pajęczynką koronki, sutek wychylający się spod koszuli, drżenie palców odbite w twoim oku, łakomie przyciśniętym do kawałka metalu. A co jest poza zasięgiem twojego zaglądania? Może przerażająca Orlandyna, która w jednej chwili

4 Tamże, s. 584. 
„z powabnego dziewczęcia z zamku Sombre Roche zmienia się w ohydne monstrum"?

„Jam nie Orlandyna - krzyknął potwór straszliwym głosem - jam Lucyfer!"5.

Ta Orlandyna, która pokusą swojej ciekawości kusi ciekawość i żądzę kochanka. Orlandyna, która - tak jak ty - zmyśla: że ogląda się w lustrze, że rozcina firankę i przez okno śledzi igraszki rozpustników. A Tybald? Tybald już wpadł w pułapkę, już jest jej - leży w brudzie i smrodzie, wśród padliny, na gnijącym ścierwie, pokornie oczekując na boże miłosierdzie, zwiedziony niczym doktor Faustus, który chciał wiedzieć wszystko, mieć wszystko, a teraz zegar odmierza jego ostatnie godziny i nic mu już nie pomoże - ani muzyka nakręconych sprężyn, ani modlitwa pustelnika, ani słowa pociechy przyjaciela.

Mądra Rebeko! „Powściągnij twe serce z obrazów, powściąnij twe usta z mowy (Sefer Jecira)". Nie zbliżaj się do smugi światła, które bije zza zamkniętych drzwi. Szukaj prawdziwej jasności, otwórz Księgę Zohar, Księgę oślepiającego Blasku. Nie patrz przez dziurkę od klucza na splecione ciała i nie słuchaj muzyki miłości. Nawet jeśli tylko zmyślasz. „Rozróżniaj w mądrości i bądź mądra w rozróżnianiu!". Nie podglądaj, patrz na drzwi! Na dziesięć desek, na 22 gwoździe. Tylko one są ci dane. Reszta to tylko złudzenie, ułamki, z których chcesz coś złożyć, rozbita mozaika, w której czai się wiele strasznych i pięknych obrazów.

Rękopis znaleziony w Saragossie to powieść okien, tarasów, luster, dziurek od klucza, powieść wyglądania, spoglądania, podglądania, śledzenia, badania powieść wieku świateł, powieść oświecenia przez dziurkę od klucza, through the Looking-Glass.

I nie chodzi tu tylko o losy głównego bohatera, który przez cały czas jest śledzony przez wszechmocnych Gomelezów, poddawany eksperymentowi, badany i podglądany jak Guliwer przez olbrzymów z Brobdingnag albo lilipuci przez Guliwera w królestwie Liliputu. Ktoś kogoś podgląda, a przecież sam jest przez kogoś podglądany.

Jak na znanym obrazie Richarda Redgrave'a: wielka twarz, wyłupiaste oczy w okrągłych okularach, które aż trzeba poprawić na nosie, bo to, co widać,jest takie małe i dziwne. I miniaturowy Guliwer w czerwonym fraku, z czarnym kapeluszem w dłoni, zgięty w szarmanckim ukłonie. Okrętowy lekarz? Kapitan Gwardii Walońskiej? Zapewne rzecz dzieje się na stole, bo obok widać

5 Tamże, s.125. 
pisarskie utensylia - pióro, kałamarz, pudełeczko na piasek o rozmiarach podróżnego kufra (przecież to tylko literatura - przypomina poczciwy wiktoriański malarz). A wokoło tłoczą się inne, nie mniej ciekawe twarze. Teraz moja kolej! Teraz ja! Teraz ja!

Albo przeciwnie, Guliwer, wsparty niedbale o zamkową wieżę (mogłaby to być jakaś skała w znajomych górach Sierra Morena), patrzy w dół, a tam kłębi się lilipucie życie (jak na rycinie innego wiktorianina, Thomasa Mortena).

Okna, lustra, dziurki od klucza rozwijają akcję Rękopisu, pojawiają się w kolejnych historiach, z których niejedna jest zwielokrotniona w wielu zwodniczych odbiciach. Przygody Alfonsa, Paszeka, Kabalisty, Rebeki, Tybalda - to wciąż ta sama opowieść. Ta sama historia widziana z różnych stron, w serii krzywych zwierciadlanych refleksów. Obraz w obrazie, teatr w teatrze, opowieść w opowieści, lustro w lustrze.

Alfons zaskoczony przez groźnego szejka Gomelezów w objęciach Eminy i Zibeldy - w tle, jak w głębi lustra, szalony Paszeko. Paszeko, po drugiej stronie lekko zmętniałej tafli szkła, widzi Alfonsa w objęciach gnijących wisielców - nagle pojawia się "szatan z ognistymi rogami i płomienistym ogonem”.

Awers i rewers. Through the Looking-Glass. Bohater jest uwięziony w lustrze, w gabinecie luster. Jedne groteskowo wyolbrzymiają lub pomniejszają, wywołując śmiech, inne fałszywie uwznioślają, co jest nie mniej śmieszne. Uwikłany w kosmos nieskończonych powtórzeń, błąkający się przez 66 dni w labiryncie opowieści, która sprawia wrażenie układu zamkniętego, gdzie nie da się odróżnić, co jest głównym wątkiem, co jego imitacją, co echem, a co parodią?.

Lustro Kabalisty i ponętne nóżki córek Salomona, a raczej zwodniczych, podwójnie zwodniczych, bo zmyślonych demonów. Lustro Rebeki i niejasne postaci androgynicznych Dioskurów, lustro, które jest jak okno - lepiej je zasłonić, bo „skoro sama nie widzę, nie będę widziana”. Okno do innego i z innego świata.

Lustro księżnej Medina Sidonia, lustro miłości i zguby - w nim odtrącona małżonka widzi po raz ostatni zazdrosnego męża (który na jej oczach zmienia się w potwora) i koniec swojego szczęścia: „W tej chwili rzuciłam wzrok

6 Tamże, s. 99.

7 E.W. Said Za fasadą "Cosi fan tutte”, w: tegoż O stylu późnym. Muzyka i sztuka pod prąd, przeł. B. Kopeć-Umiastowska, Ossolineum, Wrocław 2017, s. 72.

8 Jan Potocki Rękopis znaleziony w Saragossie, s. 172. 
na stojące naprzeciw zwierciadło; ujrzałam Mencję i księcia, ale rysy tego ostatniego przybrały tak straszliwy wyraz, że ledwie zdołałam go poznać”.

A cała historia zaczęła się przecież od okna: „Podbiegłam do okna i ujrzałam mnóstwo ludzi tłoczących się zgiełkliwie i prowadzących jakby w triumfie złoconą karetę, na której poznałam herby książąt Medina Sidonia"10.

Wreszcie zwierciadło Mamuna, w którym Avadoro ogląda swoją potajemną żonę i córkę. Lustro staje się na moment oknem, które coś odkrywa: może prawdę, a może zmyślenie: „Chcesz zobaczyć próbę? - przerwał Mamun. - Spojrzyj $\mathrm{w}$ to weneckie zwierciadło, ja zaś tymczasem pójdę zamknąć okiennice"11.

Odkryte lustra, zamknięte okna. Otwarte okna - lustrzane historie.

Okienny romans Avadora z Leonorą, która okazuje się potem dumną księżniczką Avila, przebiega według schematu żałosnej historii jego ojca don Felipe di Tintero Largo. Zmienia się tylko tonacja: zamiast opera buffa przychodzi czas na opera seria:

- Señor Avadoro - rzekła [księżniczka Avila] - Leonora przeznaczona jest na uszczęśliwienie kogoś swoją ręką. Stosownie do naszych obyczajów nie możesz u niej bywać, chociażbyś sam miał zostać jej mężem, wszelako powiem ochmistrzyni, aby otwierała jedną żaluzję od strony twoich okien, natomiast wymagam, aby twoje żaluzje były zawsze pozamykane. $^{12}$

Avadoro podgląda więc Leonorę przez wąski prześwit w żaluzji, oglądając tak naprawdę popisową rolę księżniczki Avila. Jest zwiedziony i oczarowany, podniecony podglądaniem, wplątany w przewrotny spektakl miłości i dumy. W ostatnim akcie Leonora umiera, a dom, w którym Avadoro zawarł dwuznaczne małżeństwo, zaczyna nawiedzać jej duch. Przerażona służba przyzywa pana, który postanawia śledzić zjawę przez okno. Odczepiwszy kilka żaluzji w nawiedzonych komnatach, czeka nieopodal na pojawienie się widma:

Wieczorem udałem się na moje stanowisko, a o północy znowu to samo światło zabłysło w domu naprzeciwko. Tym razem jednak spostrzegłem,

Tamże, s. 348 .

Tamże, s. 339 . 
skąd pochodziło. Kobieta w bieli, z lampą w ręku, obeszła wolnym krokiem wszystkie pokoje na pierwszym piętrze, przeszła na drugie i znikła. ${ }^{13}$

Następnej nocy widmo pojawia się znowu, a Avadoro czai się znów na posterunku za żaluzją. „Kobieta w bieli pokazała się z lampą w ręku, zbliżyła się do kolebki, długo spoglądała na dziecko, pobłogosławiła je, po czym stanęła w oknie i zaczęła patrzeć na mnie"14.

Dalej historia jest wariantem strasznej przygody Tybalda, rozkosznych nocy Alfonsa van Worden czy Paszeka. Do drzwi Avadora puka pokraczny karzeł z lampą w dłoni, który prowadzi go do zrujnowanej kaplicy. Tam oczekują go pieszczoty zmarłej żony. Potem karzeł znika, a bohater tego romansu w stylu Ann Radcliffe gubi drogę wśród ciemnych, pustych ulic, trafia po omacku na jakieś zwaliska, gdzie spędza noc. „Obudziłem się, gdy słońce już było wysoko. Leżałem pod urną z czarnego marmuru, na którym wyczytałem napis złożony złotymi literami: «Leonora Avadoro»"15.

Oczywiście jak u Ann Radcliffe wszystko to jest złudzeniem. Leonora to przebrana księżniczka Avila, której duma nie pozwoliła poślubić zwykłego szlachcica. Nie ma więc żadnych widm, a ten, kto podgląda, daje się tylko łudzić.

Lustra, okna, dziurki od klucza są groźne, wodzą i zwodzą na pokuszenie, pokazują coś, ale na odwrót albo we fragmencie, pokazują fikcje, bo lustro z natury rzeczy jest fikcją, mechanicznym odwróceniem, magicznym zwielokrotnieniem, a fragment - zadaniem do domyślenia, punktem wyjścia do hipotezy, wątłym fundamentem pracowitej intelektualnej konstrukcji.

Lustra Potockiego nie mówią o próżności, samopoznaniu czy pokucie to nie dawno zmętniałe lustra Narcyza albo Marii Magdaleny - są to lustra niebezpiecznej ciekawości, skazanej na złudzenia odbić, na logikę domysłu, grę wyobraźni, na nieuchronne i zabawne pomyłki przebrane w szaty poważnego wywodu - lustra i okna oświeconej episteme.

Jak z fragmentów, kawałków, ułamków, okruchów, strzępków, skrawków, atomów wnioskować o całości? A całość kusi i domaga się naszej ciekawości. Może w tym oknie, w tej szparze, w tej dziurce od klucza jest coś, co dopełni obraz? Ale naprzeciw okna, szpary, dziurki od klucza ktoś ustawił lustro, wiele

\footnotetext{
13 Tamże, s. 610.

14 Tamże, s. 611. 
luster, i w wypukłej maszynie naszego oka odbija się tylko jego srebrzysta, zwielokrotniona, spłaszczona wypukłość. I cienie, refleksy, powidoki, słowa, które nasza wyobraźnia przerobiła na obrazy, kształty, które nasz intelekt podstępnie wydobył z chaosu wrażeń, z ciemnego światła bycia.

Oko. Mlecznobiała, błoniasta rogówka. Kolorowa tęczówka i czarny, świdrujący otwór źrenicy. Dziurka od klucza kontrolująca obrazy, raz większa, raz mniejsza, ciasny przesmyk do tajemnicy.

„Promienie twego wzroku podciągnąłeś pod prawa optyki; jakim więc sposobem, wszędzie się przedzierając i o nic nie uderzając, nagle spotkawszy zwierciadło, wracają, jak gdyby się odbiły o jakieś ciało sprężyste? [...] Ty jednak nie wiesz tego, gdyż w gruncie rzeczy nic nie wiesz"16 - mówi w wyimaginowanym sporze z badaczem natury teolog broniący dogmatów religii.

Już w pierwszym dniu Rękopisu Emina i Zibelda z ogrodowego tarasu patrzą ciekawie na marynarzy na jeziorze Goletta, marząc o nigdy niewidzianych z bliska mężczyznach. Ta scena powróci w dniu dziesiątym, gdy Alfons z tarasu zamku Kabalisty obserwuje przybycie cygańskiego taboru. Wydaje mu się, że wśród Cyganek są jego śnione kochanki. Ale wyglądanie przez okno, jak przebudzenie, kończy się rozczarowaniem. Tak jest i tym razem. Alfons nie może wyjść na zewnątrz - brama jest zamknięta na cztery spusty.Tajemnym przejściem dociera do kraty nad potokiem oddzielającym zamek od obozu Cyganów. Tu czeka go niespodzianka: „Ale to wcale nie były moje kuzynki. Wygląd ich wydał mi się nawet bardzo pospolity i zupełnie stosowny do ich stanu. Zawstydzony moją pomyłką, wolnym krokiem wróciłem na taras"17.

Wystarczy jednak, by z powrotem znalazł się w zamku Uzedy, a znów widzi roześmianą Eminę i jej siostrę Zibeldę. Z tarasu, przez okno, przez dziurkę od klucza, w lustrze wszystko jest inne. Ale po co te igraszki? Kto mu je zafundował? Czy tylko dla pokusy? Czy dla zawrotu głowy (już nie wiem, co widzę, co jest, a czego nie ma)? Dlaczego Alfonsowi zagradza drogę krata? Niby widzi wszystko, ale nie może przekroczyć jakiejś granicy. Cóż to za granica? Między fikcją a rzeczywistością? Prawdą a fałszem? Dlaczego może patrzeć, a nie może uczestniczyć? Coś mu się wciąż wymyka, a przecież wydaje się, że już odkrył prawdę. Poddano go próbie, a za wszystkim ukrywają się Gomelezowie i don Henryk de Sa, wielkorządca prowincji.

\footnotetext{
16 Tamże, s. 444 . 
Myślałem, że w Venta Quemada dano mi usypiający napój i następnie podczas snu przeniesiono pod szubienicę. Paszeko mógł oślepnąć na jedno oko z całkiem innego przypadku, a jego miłosne stosunki i straszna przygoda z dwoma wisielcami mogły być bajką. Pustelnik, który za pomocą spowiedzi chciał wyrwać mi tajemnicę, zdawał mi się być narzędziem Gomelezów dla doświadczenia mojej stałości. ${ }^{18}$

Sprężynę zemsty małego Zota nakręca podsłuchiwanie i podglądanie czy to przez dymnik prowadzący do komnaty Principina, czy to z dębu, pod którym odbywają się niefortunne zaloty bogatego wymoczka.

Usadowiłem się na szczycie rozłożystego dębu w końcu ogrodu [...]. Młoda dziewczyna szła ze spuszczonymi oczyma i wyrazem smutku na twarzy. Usiadła na ławce, wsparła się na marmurowym stole i zaczęła gorzko płakać [...] Natenczas ujrzałem Principina zbliżającego się z kwiatami w ręku. ${ }^{19}$

Zemsta jednak nie przynosi Zoltowi szczęścia. Zwiedziony przez księcia Rocca Fiorita, morduje swoją kochankę i jej domniemanego gacha, tracąc zarazem sławę szlachetnego rozbójnika.

A czym skończyło się podglądanie cnotliwej Elwiry? Don Sancho de Peña Sombre, ukryty za żaluzjami, ,spogląda na tę, do której nie ośmielił się nigdy przemówić, a tym mniej oświadczyć swoje uczucia"20. Mąż, zazdrosny o nieśmiałego adoratora, odtrąca żonę, która wkrótce potem umiera w połogu, zostawiając na niepewny los nieuznaną przez ojca córkę.

Okno odgrywa główną rolę w przygodach Avadora. Od okna zaczyna się okrutny psikus wodzenia na pokuszenie cnotliwego nad miarę ojca Sanudo (zmętniałe, złagodzone odbicie występnego Ambrosia ze słynnego Mnicha Lewisa).,Sanudo wraz z innymi zbliżał się do okna, ale jak tylko spostrzegał, że kobiety zwracają nań uwagę, zachmurzał czoło i odchodził z pogardą"21.

Dwóch młodych uczniów mnicha, Avadoro i Veyras, szybko dostrzega dziwną sprzeczność w jego zachowaniu: „Jeśli ma takie obrzydzenie do

\footnotetext{
18 Tamże, s. 114.

19 Tamże, s. 88.

20 Tamże, s. 196. 
kobiet, po co ciśnie się do okna, jeżeli zaś pragnie je widzieć, dlaczego odwraca oczy?"22.

Niebezpieczna przebieranka, która rozbudza zmysły zakonnika i omal nie kończy się - o zgrozo! - jego upadkiem, sprowadza na figlarzy surową karę. Avadoro trafia do celi z zakratowanym oknem wychodzącym na cmentarz. Zapada noc, wschodzi księżyc, a mały więzień staje się świadkiem rzeczy strasznych i krew w żyłach mrożących: „Trzy trupy, owinięte w całuny i złożone na marach, leżały pod przysionkiem". Kapucyn i grabarze szykują ciało margrabiego Valornez do balsamowania. Nagle na murze cmentarza pojawiają się „trzy ohydne widma. Zjawy te, wraz z towarzyszącym im przeciągłym jękiem, przeraziły czterech grabarzy i naczelnika ich, kapucyna. Wszyscy uciekli, krzycząc bez miłosierdzia"23.

Ale ta obserwowana przez kraty scena to tylko złudzenie, teatralne widowisko, rozdział z gotyckiego romansu (wszystkie historie naczelnika Cyganów to w końcu tylko trawestacje, kryptocytaty, parodie - kazano mu łgać, więc łże, wykorzystując cudze opowieści, nie tylko Happeliusa, którego dzieło przegląda w zamku Kabalisty Alfons ${ }^{24}$.

Wkrótce wszystko się wyjaśnia. W roli widm występują doktor i jego studenci, którzy kradną dostojne zwłoki, zapowiadając, że niedługo wrócą po następne, śmierć dosięgła bowiem markiza Medina Sidonia. Nad podziw odważny Avadoro postanawia wykorzystać sytuację. Udaje mu się sforsować kratę i zająć miejsce nieboszczyka, który już padł łupem ciekawskiego doktora i jego pomocników. Po zwłoki markiza zgłasza się jednak żona, by pochować je w rodzinnej kaplicy. I tak przez okno i mary przyszły naczelnik Cyganów dostaje się w ręce księżnej Medina Sidonia, która daje na cmentarzu prawdziwy pokaz wdowiej rozpaczy: „O drogie szczątki najukochańszego z mężów! Dlaczegóż nie mogę, jak druga Artemizja, pomieszać waszych popiołów z moim pożywieniem, ażeby krążyły z moją krwią i ożywiły to serce, które zawsze biło dla ciebie!"25.

Ale to tylko pozór, sprytnie odegrana scena. Gdy tylko trup trafia do przydomowej kaplicy, księżna, szczerze nienawidząca męża, wybucha gniewem: „Okrutniku, tu cię więc wreszcie twoja nieubłagana wściekłość doprowadziła!

22 Tamże.

23 Tamże, s. 307.

24 Tamże, s. 163.

25 Tamże, s. 311. 
Potępiłeś nas bez wysłuchania - jakże teraz odpowiesz przed straszliwym trybunałem wieczności!". Wtóruje jej wierna służąca, jak się potem okaże, trucicielka bezlitosnego księcia: „Gdzie są - zawołała - nikczemne zwłoki tego potwora w ludzkiej postaci? Dowiem się, czy miał wnętrzności, rozerwę je własnymi rękami i ukoję moją wściekłość"26.

Nietrudno zauważyć, że cała historia księżnej Medina Sidonia jest lustrzanym odbiciem przypadków pięknej Elwiry. Tym razem jednak zniewaga i okrucieństwo zostają pomszczone, a Avadoro trafia do lochu bez okien i dopiero stamtąd wydostaje się na wolność, by zaraz wplątać się w przygody kawalera Toledo, Lopeza Suareza i Busquerosa - przygody, w których niebagatelną rolę odgrywa okno.

Tym razem jest to okno metafizyczne. Niepoprawnego rozpustnika kawalera Toledo odwiedza przyjaciel szykujący się właśnie do pojedynku na śmierć i życie. Trapiony przez złe myśli, niepewny jutra, składa obietnicę:

Posłuchaj, Toledo: tajemne przeczucie ostrzega mnie, że zginę, pragnę jednak, ażeby śmierć moja przydała się do twojego zbawienia. Opóźnię walkę aż do północy. Natenczas uważaj pilnie; jeżeli umarli mogą jakimi znakami dać się słyszeć żyjącym, w takim razie bądź przekonany, że przyjaciel twój nie omieszka upewnić cię o istnieniu tamtego świata. ${ }^{27}$

A potem jest znów scena z gotyckiej powieści. Noc, rozświetlana tylko błyskami piorunów, ogłuszona szumem ulewy i biciem zegara. Dwanaście razy: bam! bam! bam! I nagle trzy puknięcia w okiennice: puk! puk! puk! Przerażony Toledo otwiera okno i krzyczy w smaganą deszczem i wiatrem ciemność:

- Czy zginąłeś?

- Zginąłem - odpowiedział grobowy głos.

- Czy jest czyściec na tamtym świecie? - zapytał Toledo.

- Jest, i ja się w nim już znajduję - odrzekł tenże sam głos, po czym usłyszeliśmy długi, bolesny jęk ${ }^{28}$.

\footnotetext{
26 Tamże, s. 313.

27 Tamże, s. 374.

28 Tamże.
} 
Pod wpływem nieodpartego argumentum ad fenestram, rozpustnik staje się w jednej chwili pokutnikiem: owija się w płaszcz i pędzi do kościoła świętego Rocha, by zrzucić z siebie brzemię grzechów, a potem leży krzyżem przed świętym obrazem w klasztorze kamedułów! Tak, kamedułów!

Ale sprawa szybko się wyjaśnia. Nie ma dowodu na istnienie zaświatów. To tylko kolejna pułapka okna. Specjalista od intryg, okien i drabin, przeklęty Busqueros - w opowieści równoległej do historii kapitana Toledo - zaaranżował miłosną schadzkę kupieckiego syna Lopeza Suareza z Inezą z wyklętej przez Suarezów rodziny Moro. Czy to z wrodzonej przewrotności Busquerosa, czy na skutek zwykłej pomyłki drabina niezdarnego kochanka trafiła w niewłaściwe miejsce. Nagle ktoś gwałtownie otworzył okno i tą drogą Lopez Suarez trafił do Czyśćca, łamiąc przy okazji ramię i kalecząc nogi.

A okno Frasquety, przez które najpierw kusi, a później straszy zazdrosnego męża?

„Straszliwa i krwawa głowo, przestań mnie ścigać i nie wyrzucaj mi mimowolnego morderstwa"29 - woła żałosny rogacz, a potem udaje się na pielgrzymkę do św. Jakuba z Composteli, podczas gdy żona z kochankiem gorliwie świętują jego pokutę w jeszcze ciepłym małżeńskim łożu.

W całym Rękopisie jest tylko jedno okno, które - z pozoru - nie oszukuje i nie łudzi. To okno więzienia młodego Velasqueza, którego ojciec ukarał, bo młodzieniec był niezgrabny i za nic nie mógł posiąść arkanów sztuki choreograficznej.

Velasqueza co prawda nie interesowało wcale to, co jest za oknem, lecz samo okno. Tak jakby nie ciekawił go świat, lecz medium jego poznania.

Cały we łzach obróciłem oczy ku jedynemu kwadratowemu oknu znajdującemu się w izbie i zacząłem rachować szyby. Było ich dwadzieścia sześć na długość i tyleż na szerokość [...] Pomnożyłem wysokość kwadratów przez szerokość i z zadziwieniem ujrzałem, że wypadła mi prawdziwa liczba szyb [...] Powtórzyłem obliczenie, opuszczając jeden, a potem dwa pasy kwadratów, raz z szeregów pionowych, to znowu z poziomych. Zrozumiałem naówczas, że mnożenie jest tylko wielokrotnością dodawania i że powierzchnie dają się tak samo mierzyć jak długości. ${ }^{30}$ 
Abstrakcyjny świat matematyki wydaje się pewny, lecz istnieje jakby obok rzeczywistości. Velasquez próbuje zamknąć wszystko w ścisłych formułach, wzorach, wykresach, ale przebiegają one obok tego, co się dzieje, co sam przeżywa. Dwie równoległe linie, które może kiedyś spotkają się w nieskończonej kosmicznej sferze. Sprowokowany przez Rebekę geometra - postać od początku groteskowa - przeprowadza matematyczną analizę miłości, zakończoną ,formułą dwumianu, wynalezioną przez kawalera don Newtona”" ${ }^{\text {". }}$ Jednak niejasne i niepokojące uczucia, których doznaje, gdy obok jest Laura Uzeda, niewiele mają wspólnego ze sztuką matematyczną i nieuchronną logiką geometrycznego wzoru.

Nie patrz więc w okno, geometro, nie patrz! Ucz się sarabandy! Jeszcze chwila i będziesz zgubiony. Oddasz się bez reszty złudnym rozkoszom jałowych spekulacji pomimo starań ojca, którego szczęście zniszczyło zamiłowanie do nauk ścisłych.

„Nieznośny pedancie, czyliż matematyka dotąd nie nauczyła cię, skąd się biorą dzieci na świecie?"32.

Ostatnie okno Jana Potockiego znajdowało się w jego dworku w Uładówce na Ukrainie. Kiedy przyszła zima, kiedy zatrzasnął wszystkie okna w swoim Rękopisie, kiedy zamknął okiennice w swoim pokoju, zasłonił wszystkie lustra, kiedy został sam ze sobą, zrozumiał, że to już koniec. Przegrał. Wszystko, co zrobił to porażka. Niewiele zobaczył, niewiele zrozumiał, niewiele przeżył, choć tak gorliwie podglądał, podsłuchiwał i bez umiaru, bez umiaru grzeszył ciekawością. Choć zaczerniał ryzy papieru, cierpliwie układał misterne konstrukcje z kawałków tego, co zobaczył i usłyszał. A teraz to tylko ruiny i hula w nich mroźny wiatr. Wiatr i śnieg na pustyni Maroka, wiatr i śnieg pod Wielką Piramidą, wiatr i śnieg w gorących górach Sierra Morena. Juan van Worden po kolana w śniegu wymachuje szpadą. Emina i Zibelda w śnieżnej zadymce. W wietrze i śniegu maszeruje na zatracenie Wielka Armia (gdzieś tam wlecze się Alfred Potocki, który dawno zapomniał o ojcu). A wokół armia duchów: skrawki wspomnień, twarze zapisane ołówkiem pamięci, a potem niewyraźne i rozmazane, jak starte gumką, świat nieostry jak w za słabych okularach.

Jest zimno. Coraz zimniej, choć w kominku skocznie buzuje ogień i świeca dopala się kopcącym płomieniem. I jeszcze obłoczek pary nad

Tamże, s. 397-399. 
klawiaturą. Rozwiewam go palcami. To kawa, do której hrabia przyzwyczaił się na Wschodzie.

Zimnem dmucha niebo, zimnem oddycha ziemia. I nie da się go przepędzić. Ani żartem, ani rozmową, ani Rękopisem. Ta książka, która miała być tylko zabawą, teraz go zabija, oplątuje i dusi jak wąż wytatuowany od szyi do stopy na odrażającym ciele hrabiego de Peña Velez ${ }^{33}$.

Kim w końcu był? Naiwnym Alfonsem? Maszyną do snucia opowieści, której nadał imię Avadora? Busquerosem? Tak, pewno Busquerosem. A może wszystkimi: Velasquezem, Laurą szejkiem Gomelezów, szalonym Paszekiem i Pustelnikiem? Przecież, jak napisze pewien ponury Niemiec z Gdańska ${ }^{34}$, każdy człowiek jest wszystkimi ludźmi. Tyle zabawy, tyle przebieranek i wszystko na nic.

Teraz już wie. Wszechświat wiruje szaleńczo, bez ładu i składu, a jedyne jego prawa to ruch i nietrwałość. Wszechświat, który rozum podgląda przez dziurkę od klucza, zakratowane okno, lustrzaną taflę. Kosmos z wirujących kawałków, których ruch powstrzyma dopiero śmierć3 ${ }^{35}$. Może wtedy coś się z nich ułoży, odsłoni się jakiś obraz i ujawni się jakiś sens.

Jak wiele dałby, żeby się do kogoś przytulić, przezwyciężyć samotność swojego starzejącego się ciała. Zwinąć się w kłębek, odwrócić się od okna, poskromić ciekawość, patrzeć na ścianę. Nie patrzeć na okno!

Przy dziurce od klucza tłoczyło się kilkoro służących.

- Widać coś?

- Świeca, właśnie się dopala. Jakieś papiery? Cukiernica? Drut? Chyba pasek od szlafroka.

- A pan?

- Nie widzę. Za ciemno!

- Dlaczego ten pies tak wyje?

- Spróbujmy przez okno!

- Zamknął okiennice!

A wtedy ktoś uchylił mauretańskiego dachu, jak Guliwer kapelusza, i spojrzał z góry. Malutki człowieczek, odwrócony od okna, skulony na łóżku. Trzyma coś w ustach. Ludzie przy dziurce od klucza. Ludzie przy oknie.

Tamże, s. 221-222: „Głowa węża zaczynała się na prawym moim ramieniu, ciało szesnaście razy owijało się koło mojego i dopiero na wielkim palcu u prawej nogi kończyło ogonem". 
Okropny to był próg do przestąpienia. Wszakże wahanie się w tak ciężkim położeniu jeszcze mi się przykrzejszym zdało. Porywam więc świecę i wchodzę. Za mną drudzy. Wszędzie cichość wielka. Rzucam okiem po pokoju - wszędzie dość porządnie - nic w tym pomieszkaniu śmierci nie zdawało się zapowiadać gwałtownej jej ofiary. Tylko jeden zakątek, gdzie łóżko stało... ach! straszny to zakątek!... będę go długo pamiętał. Na koniec trzeba było i do niego przystąpić... Leżał na łożu Jan Potocki w szlafroku, obrócony niby twarzą do muru. ${ }^{36}$

Byle nie patrzyć w okno, byle nie patrzyć w okno.

Nie zaglądajcie w okna hrabiego Potockiego! Nie zaglądajcie w okna!

\section{Abstract}

\section{Krzysztof Mrowcewicz}

THE INSTITUTE OF LITERARY RESEARCH OF THE POLISH ACADEMY OF SCIENCES (WARSAW)

THE ALEKSANDER ZELWEROWICZ NATIONAL ACADEMY OF DRAMATICART IN WARSAW

JanPotockis Windows

Mrowcewicz explores the voyeuristic element in The Manuscript Found in Saragossa by Count Jan Potocki, a book about peeping, tracking, investigating - a novel about windows, parted curtains, keyholes, mirrors; a tale of fragments, repetitions and deceptive reflections. It can be read as the capitulation of the scholar and the writer of the enlightenment, who must eventually acknowledge that humankind's cognitive tools are imperfect, our helplessness regarding the world, which we can only perceive in fragments and reflections. In this sense Potocki's suicide - he shot himself facing a wall - becomes symbolical.

\section{Keywords}

Jan Potocki, enlightenment, cognition, knowledge, fragment, reflection, voyeurism

36 Relacja Stanisława Chołoniewskiego za: F. Rosset, D. Triaire Jan Potocki. Biografia, przeł. A. Wasilewska, W.A.B., Warszawa 2006, s. 432. 